\title{
ASSOCIATION BETWEEN OBESITY AND KNEE OSTEOARTHRITIS IN USERS OF BRAZILIAN UNIFIED NATIONAL HEALTH SYSTEM
}

\author{
ASSOCIAÇÃO ENTRE OBESIDADE E OSTEOARTRITE DE JOELHOS EM \\ USUÁRIOS DO SISTEMA ÚNICO DE SAÚDE BRASILEIRO
}

\author{
Eduardo Paul CHACUR ${ }^{1}$, Thiago Montes FIDALE ${ }^{1}$, Jean Ezequiel LIMONGI ${ }^{2}$, Fernando \\ Leonardo DINIZ ${ }^{3}$, Dalton Muller Pessoa FILHO ${ }^{4}$, Luciana da Silva MELLO ${ }^{5}$, Tarley Santos \\ OLIVEIRA $^{1}$, Kadija Mohamed SANTEE ${ }^{1}$, Fanny Gonçalves de LIMA ${ }^{6}$, Frederico Balbino \\ LIZARDO $^{7}$, Cassiano Merussi NEIVA ${ }^{5}$ \\ 1.Federal University of Catalão, Biotechnology Institute, Catalão, GO, Brazil; 2. Federal University of Uberlândia, \\ Institute of Geography, Uberlândia, MG, Brazil; 3.Faculty of Patos de Minas, Department of Health, Patos de Minas, MG, Brazil; \\ 4. Faculty of Sciences- UNESP, Human Sports Performance Optimization Laboratory, Bauru, SP, Brazil; 5. Faculty of Sciences - UNESP, \\ Metabolism and Exercise Physiology Laboratory, Bauru, SP, Brazil; 6. Federal University of Uberlândia, \\ Laboratory of Experimental Medicine, Uberlândia, MG, Brazil; 7. Federal University of Uberlândia, \\ Kinesiological Electromyography Laboratory, Uberlândia, MG, Brazil.
}

\begin{abstract}
Verify possible associations between obesity and knee OA in users of Brazilian Unified National Health System (Sistema Único de Saúde - SUS) of primary care network in Catalão-GO, Brazil. This is an observational study conducted in 2014 and 2015. A total of 81 volunteers from the Basic Attention Network in the city of Catalão, with body mass index (BMI) over $30 \mathrm{~kg} / \mathrm{m}^{2}$ in both sexes, age between 40 and 60 years, and OA on radiological examination of the knee. Obesity was classified according to BMI. The diagnosis of osteoarthritis (OA) was made clinically and by radiography according to Kellgren radiological classification. The level of physical activity was assessed using the Baecke questionnaire and the Gordon Functional Classification. The volunteers underwent an anthropometric evaluation and physical examination with inspection and palpation of the joint and subsequent radiological examination of the knee. The volunteers answered a questionnaire on the level of physical activity and functional classification. Data analysis was performed using Fisher's exact test or chi-square test was used for comparisons of two proportions. In comparisons of continuous variables, Student's t-test or the nonparametric Wilcoxon-Mann-Whitney test was used. The level of significance was set to 5\%. Practice of regular physical exercise decreases functional impairment in obese individuals with knee OA. The weight variable demonstrated a strong association with the severity of OA and degree of functionality of patients. Obesity and OA durations and lack of patient guidance are variables that may contribute to the progression of knee OA. Although the incidence among men is lower, they are more severely affected and anthropometric evaluation and physical examination are an efficacy implementations for Brazilian users of SUS.
\end{abstract}

KEYWORDS: Osteoarthritis. Obesity. Anthropometry. Primary Health Care. X-ray.

\section{INTRODUCTION}

The Unified Health System (SUS) developed policies based on its ideologies, with the purpose of serving Brazilian counties with health actions providing diagnoses and interventions for the population through Primary Health Care at the Basic Health Units (UBS) and Family Health Units (PSF) (SILVA; SILVA, 2014). Since primary health care is the gateway, with the Capacity to provide services to the community and family, these institutions focus on related issues to health promotion, in sense of changing lifestyle before impairment to health, aiming to prevent certain health problems from happening or the recovery of health, which is aimed at rehabilitation of injuries that are already installed in the individual (SCHENKER; COSTA, 2019).

Diet and proper physical activities are important factors for promoting health of a population, since if they do, between other things, prevent and treat obesity (CONCEPTS, 2013)

Obesity is one of the predictors of osteoarthritis (OA), a degenerative rheumatic disease that affects the synovial joints (DE ROSIS et al., 2010; MIZUSAKI et al., 2012).

In Brazil, OA is responsible for 30 to $40 \%$ of the consultations in rheumatology ambulatory clinics and $7.5 \%$ of removal. It is the fourth leading retirement-causing disease with a prevalence of $6.2 \%$ and second reason for sickness insurance, with 
a prevalence of $16.9 \%$ (BARBIERI; MELLO, 2018).

The incidence of $\mathrm{OA}$ is higher in women between the ages of 40 and 50 years in the menopausal period and in men over 50 years, and the high prevalence of OA in obese people has a significant socioeconomic and functional impact on health (HAJIAN-TILAKI; HEIDARI, 2007; JANSSEN; MARK, 2006).

Health promotion has guiding principles and practices focused on public policies. Taking this into account, this study was aiming to contribute to the information that helps in the elaboration of strategies to assist the well-being of the population and reduce the costs of $\mathrm{OA}$ and obesity treatments, as well as to understand the behavioural and physical characteristics of obese patients in UBS and PSF and the relationship between these characteristics and their functionality (MICHAEL; SCHLÜTER-BRUST; EYSEL, 2018).

In this perspective, the general research question for the present study was to verify the possible associations between obesity and knee OA in users of the SUS in patients of the primary health care services in the city of Catalão, Brazil.

\section{MATERIALS AND METHODS}

\section{Design}

In this observational study, cross-sectional, descriptive with a quantitative approach, the relationship between obesity and the presence and degree of knee OA, morphological and functional profile, sociocultural characteristics, and influence of education were investigated.

\section{Participants, therapists, and centres}

A total of 81 volunteers, who were users of UBS and PSF, with body mass index (BMI) above $30 \mathrm{~kg} / \mathrm{m}^{2}$ in both sexes, aged between 40 and 60 years, with knee OA and a good level of understanding, cooperation, and clinical stability at the time of evaluation, participated in the study. The volunteers were recruited from the public health system in the city of Catalão, which has two districts and an estimated population of 102,393 (IBGE 2017).

The volunteers were recruited through verbal invitations from the researcher and by community health agents in their distributed areas and through fixed invitations in the form of posters in the UBS. The exclusion criteria were eutrophia and overweightness, fracture of the lower limbs, musculoskeletal lesions other than $\mathrm{OA}$ in the knee joint, wheelchair use, neurological deficits, and the presence of immunological diseases.

\section{Intervention}

BMI

The body weight divided by the squared height $\left(\mathrm{W} / \mathrm{H}^{2}\right)$, established by the World Health Organization (WHO) to classify the BMI (OMS, 1995), was used as a criterion for the diagnosis of obesity.

\section{Waist-hip ratio (WHR)}

The WHR, is obtained by dividing the abdominal perimeter between the iliac crest and the last rib by the perimeter of the hips at the level of the femoral trochanters with the individual in the orthostatic position using the tape measure. The android distribution (central) is defined by the indexes above 0.85 in women and 0.9 in man.

\section{Abdominal circumference (AC)}

AC was also a measure used, which was determined by the measurement of the largest abdominal circumference, indicating an increase when the value was $\geq 88 \mathrm{~cm}$ in women and $\geq 102$ $\mathrm{cm}$ in men (JANSSEN; MARK, 2006).

\section{Physical examination and diagnosis of $\mathrm{OA}$}

The volunteers underwent physical examination by inspection and palpation of the knee joint and radiological examination of the knee, with the exception of those who already had the examination less than 1 year ago. OA was diagnosed clinically and by means of orthostatic radiography on anteroposterior injuries and profile of the knee joint of the participants. The radiography was classified the OA grade according to the Kellgren radiological classification (KRC) (DURYEA et al., 2013; KELLGREN; LAWRENCE, 1956) (Figure 1). 


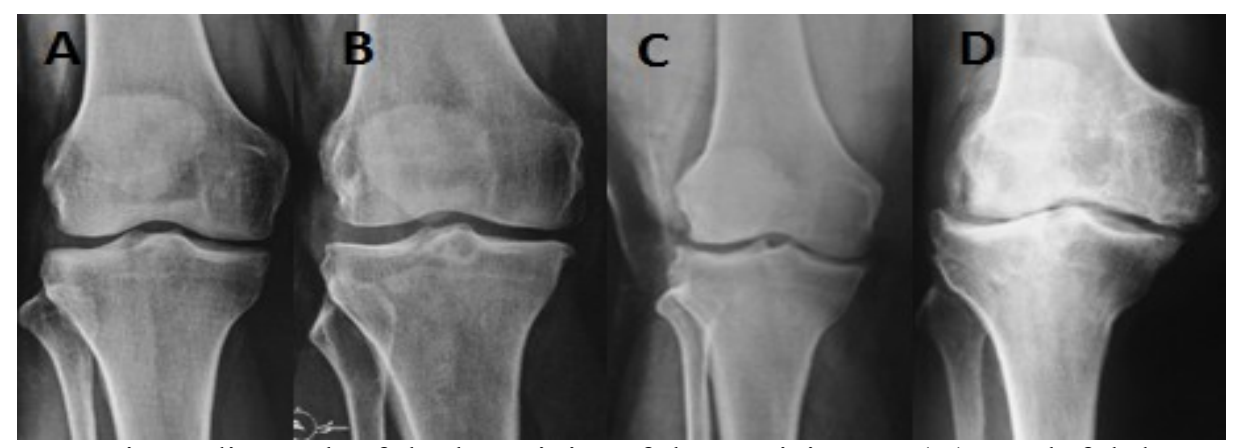

Figure 1. Anteroposterior radiograph of the knee joint of the participants. (A) Doubtful decrease in joint space and possible osteophytic lipping of the edges. (B) Well-defined osteophytes and possible decrease in joint space. (C) Moderate multiple osteophytosis, decreased well-defined joint space, initial border sclerosis, and possible angular bone deformity. (D) Wide osteophytosis, marked articular space loss, severe sclerosis of the joint edges, and well-defined angular bone deformities. Catalão, GO, Brazil, 2015

\section{Physical activity level}

To evaluate the patients' usual physical activity level, the physical activity level questionnaire by Baecke was used (FLORINDO et al., 2004). This instrument provides scores characterised by occupational activities, locomotion and leisure activities, and physical exercises performed in the last 12 months. A final score in the categories is not provided by the questionnaire. For this, we used the criteria according to Turi (TURI et al., 2014),in which the score is divided into lower quartile (1st), sedentary; intermediate quartiles (2nd and 3rd), moderately active; and upper quartile (4th), active.

\section{Functional classification}

The Gordon Functional Classification (GFC) scale was used to functionally classify knee OA patients (GORDON, 1993).

The research was carried out after approval of the Committee of Ethics in Research in Humans of the University of Franca under protocol number 565863 .

\section{Data analysis}

Data analysis was performed using the Epi Info version 3.5.4 program (www.cdc.gov/epiinfo).
Fisher's exact test or chi-square test was used for comparisons of two proportions. In comparisons of variables with more than two categories, logistic regression was used. In comparisons of continuous variables, Student's t-test or the nonparametric Wilcoxon-Mann-Whitney test was used. To verify the normality of the data, the Lilliefors test was used. Odds ratio (OR) with a 95\% confidence interval was used as a measure of association. The level of significance was set to $5 \%$.

\section{RESULTS}

\section{Participants' general characteristics}

The study included 81 obese individuals with a diagnosis of $\mathrm{OA}$ and a mean age of 51.58 years (SD 5.52), of whom 85\% were female, weight (kg) $84.7 \pm 15.2$, body mass index $\left(\mathrm{kg} / \mathrm{m}^{2}\right) 34.71 \pm$ 4.96, abdominal circumference $(\mathrm{cm}) 112.2 \pm 13.2$, hip waist ratio $0.882 \pm 0.063$, obesity duration (years) $11 \pm 7.15$ and osteoarthritis duration (years) $3 \pm 3.01$. All physical and imaging examinations were made in services of the Health Care and analyzed by the medical team and researcher (Table 1).

Table 1. Mean and standard deviation of age and anthropometric variables of participants, Catalão, GO, Brazil, 2015

\begin{tabular}{ll}
\hline Characteristics of the participants & Group OA (n= 81) \\
\hline Age (years) & $52 \pm 5.52$ \\
Weight $(\mathrm{kg})$ & $84.7 \pm 15.2$ \\
Body mass index $\left(\mathrm{kg} / \mathrm{m}^{2}\right)$ & $34.71 \pm 4.96$ \\
Abdominal circumference $(\mathrm{cm})$ & $112.2 \pm 13.2$ \\
Hip waist ratio & $0.882 \pm 0.063$ \\
Obesity duration (years) & $11 \pm 7.15$ \\
Osteoarthritis duration (years) & $3 \pm 3.01$ \\
\hline
\end{tabular}

\section{OA degree}

According to the $\mathrm{KRC}, 40 \%$ of the participants had grade $1 \mathrm{OA}, 26 \%$ grade 2 (minimum OA), $23 \%$ had 
Bioscience Journal

grade 3 (moderate $\mathrm{OA}$ ), and $11 \%$ had grade 4 (severe OA). Regarding the GFC, $38,3 \%$ of patients belong to class $1,49,4 \%$ belong to class 2 , and $12,3 \%$ belong to class 3 . It is worth mentioning that class 2 patients have limitations for sports and recreational activities.

\section{Guidelines on obesity and $\mathrm{OA}$}

Of the participants, $62 \%$ had already received general guidelines on $\mathrm{OA}$ and $56 \%$ were oriented on obesity in the UBS and ESF.

Obesity and $O A$ durations and exercise

The mean duration of obesity was 11 years (SD 7.15), and the duration of OA was 3 years (SD 3.01). Physical exercise was performed by $42 \%$ of the participants, where only $12 \%$ performed in services offered in the municipal network. Walking was the sports modality practiced by $65 \%$ of the participants; of these, $12 \%$ practiced water aerobics. Most participants in this research (79\%) performed physical exercise three times or more weekly. According to the analysis of the frequency of interpretation of the Baecke physical activity questionnaire, $22 \%$ of the participants were considered physically active, $52 \%$ were considered moderately active, and $26 \%$ were sedentary.

There was a statistical association between the numerical variables such as weight, AC, BMI, obesity and OA durations, and categorical variables, such as physical exercise, sex, and general guidelines on OA, when analysed in relation to the GFC (Table 4) and KRC scales(Tables 2 e 3) (KELLGREN; LAWRENCE, 1956; GORDON, 1993).

Table 2. Bivariate analysis between categorical variables of the patients and the Kellgren's evaluation, Catalão, GO, Brazil, 2015

\begin{tabular}{|c|c|c|c|c|c|c|c|}
\hline \multirow[t]{2}{*}{ Variables } & \multicolumn{2}{|c|}{ Grades 1 and 2} & \multicolumn{2}{|c|}{$\begin{array}{l}\text { Grades } 3 \text { and } \\
4\end{array}$} & \multirow{2}{*}{ p-value } & \multirow[t]{2}{*}{ Test } & \multirow{2}{*}{ OR (95\% CI) } \\
\hline & $\mathbf{N}$ & $\%$ & $\mathbf{N}$ & $\%$ & & & \\
\hline \multicolumn{8}{|l|}{ Sex } \\
\hline Male & 3 & 25.0 & 9 & 75.0 & $<0.01$ & Fisher's exact & $7.66(1.94-38.39)$ \\
\hline Female & 50 & 72.5 & 19 & 27.5 & & & \\
\hline \multicolumn{8}{|l|}{ Ethnicity } \\
\hline Caucasian & 26 & 66.7 & 13 & 33.3 & 0.99 & Chi-square & $1.10(0.43-2.82)$ \\
\hline Non-Caucasian & 27 & 64.3 & 15 & 35.7 & & & \\
\hline \multicolumn{8}{|l|}{ OA } \\
\hline Yes & 42 & 84.0 & 8 & 16.0 & $<0.001$ & Chi-square & $9.27(3.27-27.98)$ \\
\hline No & 11 & 35.5 & 20 & 64.5 & & & \\
\hline \multicolumn{8}{|l|}{ Obesity orientation } \\
\hline Yes & 31 & 68.9 & 14 & 31.1 & 0.61 & Chi-square & $0.71(0.27-1.81)$ \\
\hline No & 22 & 61.1 & 14 & 38.9 & & & \\
\hline \multicolumn{8}{|l|}{ Physical exercise } \\
\hline Yes & 26 & 76.5 & 8 & 23.5 & 0.12 & Chi-square & $0.41(0.15-1.11)$ \\
\hline No & 27 & 57.4 & 20 & 42.6 & & & \\
\hline \multicolumn{8}{|c|}{$\begin{array}{l}\text { Physical exercise in } \\
\text { public network }\end{array}$} \\
\hline Yes & 9 & 90.0 & 1 & 10.0 & 0.07 & Fisher's exact & $0.18(0.01-1.21)$ \\
\hline & 44 & 62.0 & 27 & 38.0 & & & \\
\hline \multicolumn{8}{|c|}{$\begin{array}{l}\text { Normal } \quad \text { physical } \\
\text { activity level (Baecke) }\end{array}$} \\
\hline Active & 14 & 77.8 & 4 & 22.2 & & $\begin{array}{l}\text { Logistic } \\
\text { regression }\end{array}$ & 1 \\
\hline Moderately active & 26 & 61.9 & 16 & 38.1 & 0.23 & & $2.15(0.60-7.69)$ \\
\hline Sedentary & 13 & 61.9 & 8 & 38.1 & 0.28 & & $2.15(0.52-8.89)$ \\
\hline
\end{tabular}


Bioscience Journal

Table 3. Bivariate analysis between numerical variables of patients and Kellgren's evaluation, Catalão, GO, Brazil, 2015

\begin{tabular}{llllll}
\hline \multirow{2}{*}{ Variables } & \multicolumn{2}{l}{ Grades 1 and 2 } & \multicolumn{2}{l}{ Grades 3 and 4 } & \multirow{2}{*}{ p-value* } \\
\cline { 2 - 5 } & Mean & SD & Mean & SD & \\
\hline Age & 51.9 & \pm 5.9 & 51.0 & \pm 4.7 & 0.52 \\
Height & 1.57 & \pm 0.07 & 1.61 & \pm 0.08 & $\mathbf{0 . 0 2}$ \\
Weight & 85.3 & \pm 10.9 & 98.2 & \pm 18.7 & $<\mathbf{0 . 0 0 1 *}$ \\
BMI & 34.6 & \pm 3.5 & 37.8 & \pm 6.5 & $\mathbf{0 . 0 4 *}$ \\
Respiratory frequency & 17.7 & \pm 2.3 & 17.7 & \pm 2.1 & 0.96 \\
Cardiac frequency & 73.0 & \pm 9.3 & 74.7 & \pm 8.5 & 0.40 \\
WHR & 0.86 & \pm 0.05 & 0.92 & \pm 0.06 & $<\mathbf{0 . 0 0 1}$ \\
Abdominal circumference & 110.3 & \pm 8.8 & 113.3 & \pm 18.9 & $\mathbf{0 . 0 2 *}$ \\
Number of cigarettes per day & 19.7 & \pm 11.5 & 15.1 & \pm 11.9 & 0.26 \\
Smoking time & 22.6 & \pm 11.1 & 25.0 & \pm 8.6 & 0.50 \\
Obesity duration & 11.9 & \pm 6.7 & 16.0 & \pm 7.2 & $\mathbf{0 . 0 1}$ \\
Osteoarthritis duration & 3.5 & \pm 2.89 & 5.30 & \pm 2.99 & $\mathbf{0 . 0 1}$ \\
Analog pain scale & 6.7 & \pm 1.3 & 7.6 & \pm 1.2 & $<\mathbf{0 . 0 0 1}$ \\
\hline
\end{tabular}

Table 4. Bivariate analysis between numerical variables of the patients and Gordon's functional classification, Catalão, GO, Brazil, 2015

\begin{tabular}{llllll}
\hline \multirow{2}{*}{ Variables } & \multicolumn{3}{l}{ Classes 1 and 2 } & \multicolumn{3}{l}{ Classes 3 and 4 } & \multirow{2}{*}{ p-value* } \\
\cline { 2 - 5 } & Mean & SD & Mean & SD & \\
\hline Age & 51.4 & \pm 5.6 & 52.6 & \pm 5.3 & 0.53 \\
Height & 1.57 & \pm 0.07 & 1.65 & \pm 0.10 & $<\mathbf{0 . 0 0 1}$ \\
Weight & 87.3 & \pm 13.0 & 106.9 & \pm 19.5 & $<\mathbf{0 . 0 0 1}$ \\
BMI & 35.2 & \pm 4.7 & 39.1 & \pm 5.2 & $\mathbf{0 . 0 2}$ \\
Respiratory frequency & 17.7 & \pm 2.4 & 17.9 & \pm 1.5 & 0.80 \\
Cardiac frequency & 74.3 & \pm 9.2 & 73.1 & \pm 5.7 & 0.68 \\
WHR & 0.88 & \pm 0.06 & 0.88 & \pm 0.07 & 0.75 \\
Abdominal circumference & 110.0 & \pm 13.1 & 120.9 & \pm 9.4 & $\mathbf{0 . 0 1}$ \\
Number of cigarettes per day & 17.9 & \pm 11.9 & 12.5 & \pm 10.6 & 0.53 \\
Smoking time & 22.9 & \pm 9.8 & 35.5 & \pm 0.70 & 0.08 \\
Obesity duration & 12.4 & \pm 6.7 & 19.7 & \pm 7.0 & $<\mathbf{0 . 0 0 1}$ \\
Osteoarthritis duration & 3.6 & \pm 2.5 & 7.6 & \pm 4.2 & $<\mathbf{0 . 0 0 1 *}$ \\
Analog pain scale & 6.8 & \pm 1.3 & 8.4 & \pm 0.89 & $<\mathbf{0 . 0 0 1}$ \\
\hline
\end{tabular}

\section{DISCUSSION}

We found that $85 \%$ of the participants were women, who showed a greater use of the health services of the UBS and also had a higher incidence of knee OA. This result is in line with that of Malta (GOSCH et al., 2010), who also observed a higher incidence of chronic non communicable diseases in women and conceded that their greater demand for health services gives them a more convenient circumstance for diagnoses related to health problems. Although the incidence of OA was lower in men, after analysis of the OR association, men were found to be 7.66 times more likely to develop more severe forms of the disease, as shown in Table 2.
BMI has a good association with body fat and $\mathrm{OA}$ due to the highly inflammatory metabolic environment found in obesity (SOWERS; KARVONEN-GUTIERREZ, 2010). In the present study, a significant association between this index was found for GFC $(p=0.02)$ and KRC $(p=0.04)$, where higher BMIs were found in individuals in classes 3 and 4 of the two scales described in Tables 3 and 4.

It was identified that $14 \%$ of participants had a BMI $>40 \mathrm{~kg} / \mathrm{m}^{2}$. Despite its low prevalence in the population $(0.81 \%)$, morbid obesity already accounts for almost a quarter of the costs attributable to obesity in the public health system, a fact observed by de Oliveira (DE OLIVEIRA; SANTOS; SILVADA, 2015). If the current 
epidemic is not controlled, the prevalence of obesity in Brazil will gradually increase in the coming years, as well as its costs and associated high incidence of $\mathrm{OA}$ in this group, affecting the financial sustainability of the Brazilian public health system.

BMI does not influence OA by only increasing mechanical overload in the joints, which may also be influenced by neurobehavioral factors and inflammatory changes. Griffin et al. identified that the levels of systemic leptin, adiponectin, and IL-1 are significantly associated with the severity of OA (GRIFFIN et al., 2010). Sartori-Cintra (SARTORI-CINTRA; AIKAWA; CINTRA, 2014) also points out that leptin may promote an inflammatory process when it assumes inflammatory characteristics, as in case of the articular cartilage.

AC also showed a significant association with OA development. Higher values were observed in individuals in classes 3 and 4 of KRC $(p=0.02)$ and GFC (p=0.01) based on Tables 3 and 4. All volunteers had an $\mathrm{AC}>99 \mathrm{~cm}$ associated with the high BMI observed. This increases the risk of developing a health problem.

A study conducted with an analysis of 88 knee radiographs evaluated the agreement between five orthopaedists, in the case of KRC. It was observed that this classification is easy to interpret and memorise, besides having a $94 \%$ degree of concordant results among the radiological evaluations performed using $\mathrm{KRC}(\mathrm{GONÇALVES} \mathrm{et}$ al., 2016).

The WHR is considered a routine measure for health education and decreases the impact of knee OA on public health (OGUNBODE et al., 2014). All volunteers in the research presented a ratio higher than 0.81 , and $37 \%$ of the total population presented a ratio higher than 0.9 , which according to the WHO (1995) represents a greater chance of developing cardiovascular complications. This group had a strong association with the degree of joint impairment $(p<0.01)$, with higher values in 58 volunteers with grades 3 and 4 KRC (Table 2). Regarding the GFC, there was no significant association (Table 3 ).

In a study of obese women with OA, $23 \%$ presented with WHR $>0.9$, but no significant differences were found in relation to the control group. In the same study, no correlation was found between the WHR and variables such as severity and functionality of $\mathrm{OA}$ and levels of physical activity(CHACUR et al., 2010).

When analysing obesity duration in years, a strong association with functional impairment $(\mathrm{p}<$
0.001) was observed. A higher mean duration of obesity was observed in patients in classes 3 and 4 of GFC as presented in Table 3 and was also associated with the degree of joint impairment $(\mathrm{p}=$ 0.01 ), where patients with KRC grades 3 and 4 showed a longer average obesity duration. These results corroborate with a study in the area (CHACUR et al., 2010).

OA duration in years was strongly associated with the functionality of patients $(\mathrm{p}<$ 0.001 ), with the mean OA duration being higher in patients in classes 3 and 4 of the GFC as presented in Table 2, and associated with the degree of OA (p $=0.01$ ), where patients with $\mathrm{KRC}$ grades 3 and 4 demonstrated a longer average OA duration. The relationship of OA duration and obesity was also investigated by Vasconcellos et al., but there were no significant results (VASCONCELOS; DIAS; DIAS, 2008).

Patient orientation was investigated in relation to both obesity and OA and the second were associated with joint impairment and functionality. The orientation to OA had a strong association with $\mathrm{KRC}$ after OR analysis. It was observed that nonoriented patients had 9.3 times more chances to develop more severe forms of OA. These data corroborate the results of a study on this theme, which concludes the importance of patient education about the disease and the importance of active behaviour in its treatment (CONCEPTS, 2013).

In a randomised study, 100 patients with knee OA were analysed, and two different groups were used. The first group performed regular exercises such as stationary cycling, stretching of the hamstring muscles, and strengthening of the quadriceps muscle, while the second group received a manual of guidelines to adjust the daily life according to the symptoms of OA. It was observed that the 8-week strength training exercises were more effective than only the pain control guidelines, control of the function, and stiffness of the knee joint of the patients (MIZUSAKI et al., 2012).

The usual physical activity level of the participants did not show any association with the evolution of OA in this analysis (Tables 1 and 4), but exercise showed an important protection factor. Patients who performed exercises had $87 \%$ less chance to develop greater functional impairment according to the OR analysis (Table 4).

Among sports, walking (73\%) was the most practiced in the total sample. According to Del Duca (DEL DUCA et al., 2014), walking is an activity considered as preferential for the possibility of practicing together by individuals living in company. For patients, the general guidelines on 
efficient walking were emphasised by the researcher.

$49 \%$ of adult individuals are physically inactive according to the national average reported by the WHO in 2011. It can be observed in our study that the sample is below the national average (WHO. WORLD HEALTH ORGANIZATION.; WHO, 2010).

Orientation to physical activity indicated a functional and qualitative improvement in patients with knee OA, even in individuals indicated for arthroplasty (FERNANDES; NOGUEIRA, 2016).

Notably, $62 \%$ of individuals reported having been oriented about $\mathrm{OA}$ at the time of their diagnosis and $56 \%$ on obesity in the UBSs and PSFs. In a study on interprofessionality in the family health strategy, Farias et al (2017) consider that interdisciplinarity has great potential to support the integral actions and is more resolutive about potential problems, especially when focused on the needs of the user. In this context, it is observed that the interdisciplinary perspective is necessary even in individualised care; moreover, the expanded conception of health, which guides integral care, implies that, in all activities, it is necessary to have knowledge integration, including individual care, so that individuals can solve their health problems (FARIAS et al., 2017).

One way to include and list possible improvements to SUS is promotion of public policies and use data collected in population to outline guidelines and objectives to be implemented in individual and collective health, this study questions were raised that should be taken into account regarding the construction of actions assigned to professionals, encouraging interdisciplinary and correct orientation, which proved to be beneficial in issues related to the recovery of OA (DIAS et al, 2018).

\section{CONCLUSION}

It can be concluded that obesity and OA durations and the lack of orientation of the patient are variables that possibly contribute to the evolution of knee OA.

Men, despite having a lower incidence, are more severely affected, which shows how essential the strategies of active search in homes as recommended by the PSF and the expansion of the public services of the UBS and PSF beyond business hours are, so that more people are reached. Particularly in men, anthropometric variables are effective and low-cost measures should be widely used in the evaluation and clinical follow-up of obese individuals using public health services.

In this since, can be evidenced the importance of actions for promotion and prevention of diseases in primary care, which individual and community provide the maintenance an implement of life quality. In view of specificity in computed tomography diagnostic examinations to show degree degeneration of osteoarthritis, this becomes a limiting factor of the study, since high cost and difficulty of access in the SUS, when compared to radiographic examination.

RESUMO: Verificar possíveis associações entre obesidade e osteoartrite (OA) de joelho em usuários do Sistema Único de Saúde (SUS) da cidade de Catalão-GO. Trata-se de um estudo observacional realizado entre 2014 e 2015. Participaram deste estudo 81 voluntários da Rede de Atenção Básica da cidade de Catalão, com índice de massa corporal (IMC) acima de $30 \mathrm{~kg} / \mathrm{m} 2 \mathrm{em}$ ambos os sexos, idade entre 40 e 60 anos e OA no exame radiológico do joelho. A obesidade foi classificada de acordo com o IMC. O diagnóstico de OA foi feito clinicamente e por radiografia de acordo com a classificação radiológica de Kellgren. O nível de atividade física foi avaliado pelo questionário de Baecke e pela Classificação Funcional de Gordon. Os voluntários responderam a uma avaliação antropométrica e exame físico com inspeção e palpação da articulação e posterior exame radiológico do joelho. Os voluntários responderam a um questionário sobre o nível de atividade física e classificação funcional. Os dados foram analisados por meio do teste exato de Fisher ou o teste do qui-quadrado foi utilizado para comparações de duas proporções. Nas comparações das variáveis contínuas, utilizou-se o teste $\mathrm{t}$ de Student ou o teste não paramétrico de Wilcoxon-Mann-Whitney. O nível de significância foi estabelecido em $5 \%$. A prática de exercício físico regular diminui o comprometimento funcional em indivíduos obesos com OA de joelho. A variável peso demonstrou uma forte associação com a gravidade da OA e o grau de funcionalidade dos pacientes. Obesidade e duração da OA e falta de orientação do paciente são variáveis que podem contribuir para a progressão da OA do joelho. Embora a incidência entre os homens seja menor, eles são mais gravemente afetados. Adicionalmente, a avaliação antropométrica e o exame físico são procedimentos complementares eficazes para usuários brasileiros do SUS.

PALAVRAS-CHAVE: Osteoartrite. Obesidade. Antropometria. Atenção Primária à Saúde. Raio X. 
Bioscience Journal

\section{REFERENCES}

BARBIERI, A. F.; MELLO, R. A. As causas da obesidade: uma análise sob a perspectiva materialista histórica. Conexões, v. 10, n. 1, p. 121-141, 2018. Disponível em:

$<$ https://periodicos.sbu.unicamp.br/ojs/index.php/conexoes/article/view/8637693/5384>. Acesso: 12 ago. 2018. https://doi.org/10.20396/conex.v10i1.8637693

CHACUR, E. P.; SILVA, L.O.; LUZ, G.C.P.; KAMINICE, F.D.; CHEIK, N.C . Anthropometric and Q angle assessment in obese women with knee osteoarthritis. Fisioterapia e Pesquisa, v. 17, n. 3, p. 220-224, 2010. Disponível em: <http://www.scielo.br/pdf/fp/v17n3/06.pdf>. Acesso: 01 jul. 2016.

https://doi.org/10.1590/S1809-29502010000300006

CONCEPTS, C.; REZENDE, M.U. Conceitos Atuais em Osteoartrite. Acta Ortop Bras, v. 21, n. 2, p. 120 122, 2013 .Disponível em:<http://www.scielo.br/pdf/aob/v21n2/a10v21n2.pdf>. Acesso: 12 ago 2018. https://doi.org/10.1590/S1413-78522013000200010

DE OLIVEIRA, M. L.; SANTOS, L. M. P.; SILVADA, E. N. Direct healthcare cost of obesity in brazil: An application of the cost-of-illness method from the perspective of the public health system in 2011. PLoS ONE, v. 10, n. 4, p. 1-15, 2015. Disponível

em: $<$ http://journals.plos.org/plosone/article/file?id=10.1371/journal.pone.0121160\&type=printable $>$. Acesso: 10 abr. 2018. https://doi.org/10.1371/journal.pone.0121160

DE ROSIS, R. G.; PAULO, S.M.; KAIRALLA, M. Osteoarthritis: clinical and epidemiological assessment of elderly patients in institution of long-stay. Rev Bras Clin Med, v. 8, n. 2, p. 101-108, 2010. Disponível em: $<$ http://files.bvs.br/upload/S/1679-1010/2010/v8n2/a003.pdf>. Acesso:12 ago. 2018.

DEL DUCA, G. F.; NASHAS, M.V.; HALLAL, P.C.; PERES, K.G. Atividades físicas no lazer entre adultos de Florianópolis, Santa Catarina, Brasil: estudo populacional sobre as características das práticas e de seus praticantes. Ciência \& Saúde Coletiva, v. 19, n. 11, p. 4595-4604, 2014. Disponível em:

$<$ http://www.scielo.br/pdf/csc/v19n11/1413-8123-csc-19-11-4595.pdf.>. Acesso: 01 jul. 2016.

https://doi.org/10.1590/1413-812320141911.16732013

DIAS, M.S.A; OLIVEIRA, I.P; SILVA, L.M.S; VASCONCELOS, M.I.O; MACHADO, M.F.A.S; FORTE, F.D.S; SILVA, L.C.C. Política Nacional de Promoção da Saúde: um estudo de avaliabilidade em uma região de saúde no Brasil. Ciênc. saúde colet. Rio de Janeiro, RJ, v. 23, n. 1, jan. 2018. Disponível em:

$<$ https://www.scielosp.org/article/csc/2018.v23n1/103-114/>. Acesso: 22 jun. 2019.

https://doi.org/10.1590/1413-81232018231.24682015

DURYEA, J.; LU, B.; AHMAD, O.; ZHANG, F.F.; DRIBAN, J.B.; LAPANE, K.L . Soft drink intake and progression of radiographic knee osteoarthritis: data from the osteoarthritis initiative. BMJ Open, v. 3, n. 7, p. 1-7, 2013. Disponível em: $<$ https://www.ncbi.nlm.nih.gov/pmc/articles/PMC4244434/pdf/bmjopen-2014006286.pdf.>. Acesso: 15 mai. 2017. https://doi.org/10.1136/bmjopen-2013-002993

FARIAS, D. N.; RIBEIRO, K.S.Q.S.; ANJOS, U.U.; BRITO, G.E.G. Interdisciplinaridade e

Interprofissionalidade Na Estratégia Saúde Da Família. Trabalho, Educação e Saúde, v. 16, n. 1, p. 141-162, 2017. Disponível em: <http://www.scielo.br/pdf/tes/v16n1/1678-1007-tes-1981-7746-so100098.pdf. $>$. Acesso: 12 ago. 2018. https://doi.org/10.1590/1981-7746-sol00098

FERNANDES, R.S.C.; NOGUEIRA, M.P. Efeitos Da Orientação Da Atividade Física Em Pacientes Com Osteoartrite Avançada Do Joelho. Revista Brasileira de Medicina do Esporte, v. 22, n. 4, p. 302-305, 2016. Disponível em: <http://www.scielo.br/pdf/rbme/v22n4/1517-8692-rbme-22-04-00302.pdf $>$. Acesso: 30 jan. 2017. https://doi.org/10.1590/1517-869220162204156152

FLORINDO, A. A. et al. Metodologia para a avaliação da atividade física habitual em homens com 50 anos ou mais. Revista de Saude Publica, v. 38, n. 2, p. 307-314, 2004. Disponível em: 
$<$ http://www.scielo.br/pdf/rsp/v38n2/19793.pdf>. Acesso: 15 mai. 2017. https://doi.org/10.1590/S003489102004000200022

GONÇALVES, F.B.; RODRIGUES, A.A.; KARAM, F.C.; SCORSATTO, C.; MARATINS, C.; PIRES, L.A.S. Avaliação da reprodutibilidade das diferentes descrições da classificação de Kellgren e Lawrence para osteoartrite do joelho. Revista Brasileira de Ortopedia, v. 51, n. 6, p. 687-691, 2016. Disponível em: $<\mathrm{http}: / /$ www.amrigs.org.br/revista/56-02/original1.pdf.>. Acesso: 01 jul. 2016.

https://doi.org/10.1016/j.rbo.2016.02.009

GORDO N.F. Arthritis Your Complete Exercise Guide. Dallas, Texas: Human Kinetics, 1993.

GOSCH, C.S.; MALTA, D.C.; CASTRO, A.M.; CRUZ, D.K.A.; BRESSAN, A.; NOGUEIRA, J.D. A Política Nacional de Promoção da Saúde e a agenda da atividade física no contexto do SUS. Epidemiologia e Serviços de Saúde, v. 18, n. 1, p. 79-86, 2010. Disponível em: <http://scielo.iec.gov.br/pdf/ess/v18n1/v18n1a08.pdf.>. Acesso: 15 mai. 2017.

GRIFFIN, T.M.; FERMOR, B.; HUEBNER, J.L.; KRAUS, V.B.; RODRIGUIZ, R.M.; WESTSEL,W.C. Dietinduced obesity differentially regulates behavioral, biomechanical, and molecular risk factors for osteoarthritis in mice. Arthritis Research and Therapy, v. 12, n. 4, 2010. Disponível

em:<http://www.ncbi.nlm.nih.gov/pmc/articles/PMC2945020/pdf/ar3068.pdf.>. Acesso: 28 jun. 2016. https://doi.org/10.1186/ar3068

HAJIAN-TILAKI, K. O.; HEIDARI, B. Prevalence of obesity, central obesity and the associated factors in urban population aged 20-70 years, in the north of Iran: A population-based study and regression approach. Obesity Reviews, v. 8, n. 1, p. 3-10, 2007. Disponível em:

$<$ https://onlinelibrary.wiley.com/doi/pdf/10.1111/j.1467-789X.2006.00235.x>. Acesso: 12 ago. 2018. https://doi.org/10.1111/j.1467-789X.2006.00235.x

IBGE. Instituto Brasileiro de Geografia e Estatística (IBGE). População estimada 2017. Disponível em: $<$ https://cidades.ibge.gov.br/brasil/go/catalao/panorama.>. Acesso: 06 jun. 2018.

JANSSEN, I.; MARK, A. E. Separate and combined influence of body mass index and waist circumference on arthritis and knee osteoarthritis. International Journal of Obesity, v. 30, n. 8, p. 1223-1228, 2006. Disponível em: <https://www.nature.com/articles/0803287.pdf.>. Acesso: 12 ago. 2018.

https://doi.org/10.1038/sj.ijo.0803287

KELLGREN, J. H.; LAWRENCE, J. S. Radiological Assessment Of Osteo Arthrosis. n. 3, p. 494-502, 1956. Disponível em: <https://www.ncbi.nlm.nih.gov/pmc/articles/PMC1006995/pdf/annrheumd00183-0090.pdf.>. Acesso: 15 mai. 2017.

MICHAEL, J.W.P.; SCHLÜTER-BRUST, K.U.; EYSEL, P. The Epidemiology, Etiology, Diagnosis, and Treatment of Osteoarthritis of the Knee. Deutsches Aerzteblatt Online, v. 107, n. 9, 2018. Disponível em: $<$ https://www.ncbi.nlm.nih.gov/pmc/articles/PMC2841860/pdf/Dtsch_Arztebl_Int-107-0152.pdf.>. Acesso: 12 ago. 2018.

MIZUSAKI, A.; OLIVEIRA, A.M.I.; PECCIN, M.S.; SILVA, K.N.G.; TEIXEIRA, L.E.P.P.; TREVIANI, V.F.M. Funcional E Dor Em Pacientes Com Osteoartrite De Joelhos : Ensaio Clínico Randomizado. v. 52, n. 6, p. 876-882, 2012. Disponível em: $<$ http://www.scielo.br/pdf/rbr/v52n6/v52n6a06.pdf.>. Acesso: 12 ago. 2018. https://doi.org/10.1590/S0482-50042012000600006

OGUNBODE, A. Physical Functionality and Self-Rated Health Status of Adult Patients with Knee

Osteoarthritis Presenting in a Primary Care Clinic. Ethiopian Journal of Health Sciences, v. 24, n. 4, p. 319, 2014. Disponível em: <https://www.ncbi.nlm.nih.gov/pmc/articles/PMC4248031/pdf/EJHS2404-0319.pdf.>. Acesso: 25 jun. 2019. https://doi.org/10.4314/ejhs.v24i4.7 
Bioscience Journal

Organização Mundial de Saúde. Physical status: The use and interpretation of anthropometry. , 1995. Disponível em: <http://www.who.int/childgrowth/publications/physical_status/en/.>. Acesso 15 mai. 2017.

SARTORI-CINTRA, A. R.; AIKAWA, P.; CINTRA, D. E. C. Obesidade versus osteoartrite: muito além da sobrecarga mecânica. Einstein (São Paulo), v. 12, n. 3, p. 374-379, 2014. Disponível em:

$<$ http://www.scielo.br/pdf/eins/2014nahead/1679-4508-eins-1679-45082014RB2912.pdf.>. Acesso: 28 jun. 2016. https://doi.org/10.1590/s1679-45082014rb2912

SCHENKER, M; COSTA, D.H. Avanços e desafios da atenção à saúde da população idosa com doenças crônicas na Atenção Primária à Saúde. Ciênc. saúde coletiva, v. 24, n. 4, p. 1369-1380, apr. 2019. Disponível em: <http://dx.doi.org/10.1590/1413-81232018244.01222019.>. Acesso: 20 jun 2018.

https://doi.org/10.1590/1413-81232018244.01222019

SILVA, F.A.; SILVA, I.R.. Sentidos de saúde e modos de cuidar de si elaborados por homens usuários de Unidade Básica de Saúde - UBS. Ciência \& Saúde Coletiva, v. 19, n. 2, p. 417-428, 2014. Disponível em: <http://www.scielo.br/pdf/csc/v19n2/1413-8123-csc-19-02-00417.pdf.>. Acesso: 12 ago. 2018. https://doi.org/10.1590/1413-81232014192.04712013

SOWERS, M.R; KARVONEN-GUTIERREZ, C.A. The evolving role of obesity in knee osteoarthritis. Curr Opin Rheumatol, v. 22, n. 5, p. 533-537, 2010. Disponível em:

<https://www.ncbi.nlm.nih.gov/pmc/articles/PMC3291123/pdf/nihms358648.pdf.>. Acesso: 10 abr. 2018. https://doi.org/10.1097/BOR.0b013e32833b4682

TURI, B.C.; CODOGNO, J.S.; FERNANDES, R.A.; MONTEIRO, H.L. Physical activity, adiposity and hypertension among patients of public healthcare system. Revista Brasileira de Epidemiologia, v. 17, n. 4, p. 925-937, 2014. Disponível em:

$<$ https://www.scielosp.org/article/ssm/content/raw/?resource_ssm_path=/media/assets/rbepid/v17n4/pt_1415790X-rbepid-17-04-00925.pdf.>. Acesso: 15 mai. 2017. https://doi.org/10.1590/1809-4503201400040011

VASCONCELOS, K.; DIAS, J. M.D.; DIAS, R.C. Impacto do grau de obesidade nos sintomas e na capacidade funcional de mulheres com osteoartrite de joelhos Impact of the degree of obesity on symptoms and functional capacity of women with knee osteoarthritis. Fisioterapia e Pesquisa, v. 15, n. 2, p. 125-130, 2008. Disponível em: <http://www.scielo.br/pdf/fp/v15n2/03.pdf.>. Acesso: 01 jul. 2016. https://doi.org/10.1590/S1809-

29502008000200003

WHO. WORLD HEALTH ORGANISATION. Global status report on noncommunicable diseases. World Health Organisation, p. 176, 2010. Disponível em:

<http://www.who.int/nmh/publications/ncd_report2010/en/.>. Acesso: 02 jul. 2016. 